\title{
AKTIVITAS HEPATOPROTEKTIF PERASAN DAUN BINAHONG PADA TIKUS PUTIH YANG DIINDUKSI PARASETAMOL
}

\author{
*Budi Siswanto'*Ranti Dwi Astriani
}

\begin{abstract}
Abstrak
Pemanfaatan bahan-bahan alam sebagai obat tradisional mulai dikembangkan. Hal ini disebabkan masyarakat menyadari efek samping yang ditimbulkan dari obat-obat sintetik lebih besar dibandingkan dengan obat-obat yang terbuat sari alam, selain itu juga harganya yang terjangkau, mudah dibuat dan mudah juga diperolehnya (Wijayakusuma, dkk, 1996). Obat tradisional adalah bahan atau ramuan bahan berupa tumbuhan, bahan hewan, bahan mineral dalam bentuk sediaan sarian atau campuran dari bahan-bahan tersebut yang secara turun menurun telah digunakan untuk pengobatan berdasarkan empiris (heyne, 1987), Meningkatnya pengetahuan masyarakat mengenai kegunaan tumbuhan herbal, maka banyak masyarakat yang beralih memanfaatkan tumbuhan herbal sebagai bahan pengobatan alternatif. Binahong ( Andredera cordifolia (Ten.) Steenis, merupakan salah satu tumbuhan herbal yang memiliki khasiat sebagai tanaman bahan obat yang digunakan untuk berbagai penyakit yang tidak merugikan bagi tubuh. Binahong berasal dari dataran China dengan nama asalnya adalah Dheng san chi. Uniknya, hampir semua bagian dari tanaman ini dapat digunakan sebagai obat. Dari pembahasan tersebut dapat disimpulkan bahwa peningkatan Aktivitas kadar AST dan ALT serum darah hewan coba yang diinduksi paracetamol dapat dihambat oleh ekstrak daun binahong, karena daun binahong mempunyai kemampuan untuk melindungi kerusakan hepar hewan coba tikus putih, kerusakan hepar secara akut dapat terlihat dari adanya peningkatan kadar ALT lebih tinggi daripada kadar AST, sedangkan pada kerusakan hepar yang bersifat kronis kadar AST lebih tinggi dari ALT. Saran perlu dilakukan penelitian lebih lanjut dengan dosis ekstrak yang optimum dan jangka waktu penelitian lebih lama, selain itu perlu dilakukan penelitian secara histopatologis pada organ tubuh yang ingin dilihat.
\end{abstract}

\section{Kata Kunci ; Hepatoprotektif, Perasan Daun Binahong, Tikus Putih, induksi Parasetamol}

*) Dosen Jurusan Analis Kesehatan Poltekkes Kemenkes Banten

\section{Pendahuluan}

Indonesia adalah negara dengan

wilayah yang beriklim tropis sehingga terdapat berbagai macam tumbuhan herbal. Tumbuhan herbal ialah tumbuhan yang mempunyai khasiat untuk

$$
\begin{aligned}
& \text { menyembuhkan penyakit. Seiring } \\
& \text { meningkatnya kesadaran masyarakat } \\
& \text { terhadap kesehatan maka pemanfaatan } \\
& \text { bahan-bahan alami semakin mendapat } \\
& \text { perhatian. Pelczar dan Chan (1988) } \\
& \text { menyatakan banyak zat kimia dapat }
\end{aligned}
$$


menghambat atau mematikan mikroorganisme.

Pemanfaatan bahan-bahan alam sebagai obat tradisional mulai dikembangkan. Hal ini disebabkan masyarakat menyadari efek samping yang ditimbulkan dari obat-obat sintetik lebih besar dibandingkan dengan obat-obat yang terbuat sari alam, selain itu juga harganya yang terjangkau, mudah dibuat dan mudah juga diperolehnya (Wijayakusuma, dkk, 1996).

Obat tradisional adalah bahan atau ramuan bahan berupa tumbuhan, bahan hewan, bahan mineral dalam bentuk sediaan sarian atau campuran dari bahanbahan tersebut yang secara turun menurun telah digunakan untuk pengobatan berdasarkan empiris (heyne, 1987), Meningkatnya pengetahuan masyarakat mengenai kegunaan tumbuhan herbal, maka banyak masyarakat yang beralih memanfaatkan tumbuhan herbal sebagai bahan pengobatan alternatif.

Binahong ( Andredera cordifolia (Ten.) Steenis, merupakan salah satu tumbuhan herbal yang memiliki khasiat sebagai tanaman bahan obat yang digunakan untuk berbagai penyakit yang tidak merugikan bagi tubuh. Binahong berasal dari dataran China dengan nama asalnya adalah Dheng san chi. Uniknya, hampir semua bagian dari tanaman ini dapat digunakan sebagai obat.

Secara ilmiah tanaman ini telah banyak digunakan sebagai antimikroba seperti bakteri yang dapat menyebabkan infeksi adalah Staphylococcus aureus, dimana mikroba ini dapat menyebabkan penyakit seperti pneumonia, meningitis, empiema, endokarditis atau sepsis dengan supurasi di tiap organ (Jawetz et al, 2001). Penelitian mengenai aktivitas antibakteri daun Binahong dan kandungan metabolit sekundernya pernah dilakukan, bahwa dalam simplisia daun Binahong terkandung senyawa alkaloid, polifenol dan saponin (Hidayati, 2009). Senyawa-senyawa ini dapat bermanfaat untu mengobatai penyakit seperti ; DM, penyakit hepatitis, gangguan kardiovaskuler; tekanan darah, kolestero darah yang tinggi, pembekuan darah, pengerasan ini dapa digpembuluh darah dan stres.

\section{Hepatoprotektif (pelindung hati)} adalah senyawa obat yang memiliki efekteurapeutik, untuk memulihkan, memelihara, dan mengobati kerusakan dari fungsi hati. Penyakit-penyakit kerusakan fungsi antara lain hepatitis, 
kanker, hati berlemak, insufisiensi hati, sirosis hati, sakit pada ulu hati, batu empedu, radang kandung empedu, jumlah getah empedu yang sedikit, penyakit kuning, dan lain sebagainya. Sampai saat ini belum ada obat yang disetujui sebagai hepatoprotektor, tetapi untuk tanamantanaman obat yang kini dipasarkan menjadi jamu atau campuran jamu yang dipasarkan di Indonesia telah diakui sebagai hepatoprotektor, misalnya Hepasil dari Kalbe Farma, Hepacomb dari Sidomuncul, Hepagard dari Phapros, dan berbagai produk lainnya (Anonimus, 2000).

Beberapa tanaman obat yang telah diteliti dan diakui bersifat sebagai hepatoprotektif adalah tanaman kunyit, sambiloto, dan temulawak. Ketiga tanaman tersebut diketahui mengandung antioksidan yang sangat tinggi, dimana antioksidan ini sangat diperlukan dalam menangkal radikal bebas yang merupakan salah satu penyebab kerusakan hati. Selain ketiga tanaman tersebut, masih banyak tanaman obat lain yang ada di Indonesia yang diketahui mempunyai senyawa antioksidan, namun efek hepatoprotektif nya belum dibuktikan secara ilmiah, salah satunya adalah tanaman Binahong (Andredera
cordifolia(Ten.) Steenis).(Setiaji, 2009). Tanaman ini merupakan salah satu tanaman obat di Indonesia yang umum ditemukan di pekarangan rumah, kebun, tempat pembuangan sampah dan lainlain.

\section{Metode Penelitian}

Penelitian ini bersifat eksperimen secara deskriptif yang menganalisa perubahan enzim hepar. Penelitian ini dilakukan di labolatorium analis kesehatan, dilakukan mulai bulan April 2015 sd Mei 2015. Populasi sampel; 15 ekor tikus putih jenis Rattus Novergicus Cara pengumpulan data; data dikumpulkan dengan cara memeriksa kadar AST dan ALT dalam plasma darah yang dilakukan setelah perlakuan 24 jam, kemudian data dikumpulkan, diolah melalui coding, prossesing dan cleaning. Analis data digunakan uji t- defenden dan Anova

\section{Hasil Penelitian dan Pembahasan}

Hasil dan Pembahasan Daun Binahong ( Andredera cordifolia (Te.) Steenis)

Hasil penelitian ini didapatkan kadar aktivitas AST dan ALT seperti yang terlihat pada Tabel 1 dan 2 . 


\section{Tabel 1}

Kadar AST (U/I) tikus putih kontrol dan yang diberi ekstrak daun binahong

\begin{tabular}{|c|c|c|c|c|c|}
\hline Tikus & Klpk A & Klpk B & Klpk C & Klpk D & Klpk E \\
\hline 1 & 23 & 66 & 36 & 30 & 29 \\
\hline 2 & 28 & 76 & 39 & 36 & 32 \\
\hline 3 & 31 & 70 & 35 & 39 & 31 \\
\hline & $27.33 \pm 4.0$ & $70.67 \pm 5.0$ & $36.67 \underline{ \pm 2.1}$ & $35 \pm 4.6$ & $30.67 \pm 1.5$ \\
\hline
\end{tabular}

\section{Tabel 2}

Kadar ALT (U/I) tikus putih kontrol dan yang diberi ekstrak daun binahong

\begin{tabular}{|c|c|c|c|c|c|}
\hline Tikus & Klpk A & Klpk B & Klpk C & Klpk D & Klpk E \\
\hline 1 & 40 & 87 & 49 & 77 & 76 \\
\hline 2 & 48 & 89 & 87 & 83 & 80 \\
\hline 3 & 55 & 94 & 79 & 87 & 74 \\
\hline & $47.67 \pm 7.5$ & $90.007 \pm 3.6$ & $71.67 \pm 20$ & $82.33 \pm 5.0$ & $76.67 \pm 3.1$ \\
\hline
\end{tabular}

Keracunan paracetamol pada hepar dapat terlihat dari kadar AST dan ALT setelah pemberian paracetamol dosis 2.5 $\mathrm{g} / \mathrm{Kg} \mathrm{BB}$ dan setelah perlakuan aquades terlihat pada tabel 1 dan 2 kelompok A dan B, yaitu sebesar $70 \pm 5 \mathrm{U} / \mathrm{I}$ dan $90 \pm$ 4. Kadar AST dan ALT tersebut lebih tinggi bila dibandingkan dengan kelompok A yang diberikan aquades yaitu sebesar $27.33 \pm 4$ U/I, dan $47.67 \pm$ 7.51. Hal ini menunjukkan bahwa pemberian paracetamol menyebabkan terjadinya kerusakan pada hepar tikus percobaan.
Aktivitas kadar AST serum darah tikus yan diinduksi paracetamol yang diberi perlakuan ekstrak daun Binahong dengan dosis $50 \mathrm{mg} / \mathrm{Kg} \mathrm{BB}, 100 \mathrm{mg} / \mathrm{Kg}$ BB dan 200 mg/Kg BB ( Kelompok C, D dan E) berturut-turut sebesar $36.67 \pm$ $21 \mathrm{U} / \mathrm{I}, 29.67 \pm 2.1 \mathrm{U} / \mathrm{I}$, dan $45.67 \pm 4.16$ U/I, Bila dibandingkan dengan tikus yang diberi paracetamol saja ( kelompok B) aktivitas kadar AST tersebut berbeda secara bermakna $(\mathrm{P}<0.05)$ lebih rendah, begitu juga kadar ALT serum darah kelompok B yang diinduksi paracetmol sebesar $90 \pm 36$ U/I, lebih tinggi dari kelompok yang diberi perlakuan ekstrak 
daun Binahong, yaitu ; $71.67 \pm 20.03$ U/I, $82.33 \pm 5.0 \mathrm{U} / \mathrm{I}$, dan $85 \pm$ 1.0. Kadar AST pada kelompok $\mathrm{C}$ dan $\mathrm{E}$ terlihat sedikit lebih tinggi bila di bandingkan dengan kadar normal Aktivitas serum darah tikus yaitu 17 - 30 U/I, begitu juga kadar AST kelompok D dan E sedikit lebih tinggi dari kadar normal Aktivitas serum darah tikus yaitu 45 80 U/I. Tetapi secara statistik menunjukkan hasil yang bermakna, Donatus dan kawan-kawan (1983) dalam penelitiannya mengatakan bahwa ; kerusakan hepar terjadi karena adanya peningkatan kadar AST dan ALT $10 \mathrm{x}$ lebih tinggi.

Pada kedua tabel terlihat semakin tinggi dosis pemberian perlakuan ekstrak daun Binahong semakin besar daya untuk menghambat kerusakan sel hepar yang ditandai dengan rendahnya aktivitas kadar AST dan ALT serum darah tikus percobaan, hal ini terjadi kemungkinan disebabkan oleh adanya aktivitas daun binahong yang mempunyai antioksidan berupa senyawa flavonoid dan fenol (Alan dan Miller 1996), senyawa Flavonoida, Fenifflavonoida dan alkaloida, Flavoid dapat menghambat kerusakan sel dengan cara mengikat radikal bebas sehingga hepar tikus percobaan dapat terlindungi dari kerusakan, radikal bebas dalam penelitian ini disebabkan dengan pemberian paracetamol dengan dosis 2.5 $\mathrm{g} / \mathrm{Kg} \mathrm{BB}$, yang dapat menyebabkan kerusakan pada hepar sehingga enzim AST dan ALT akan keluar dari sel hepar, enzim yang keluar ini akan meningkatnkan kadarnya di dalam serum darah sehingga dapat dijadikan indikator adanya kerusakan hepar (Harborne JB 1973).

Hasil penelitian ini menunjukkan bahwa peningkatan kadar AST dan ALT serum darah tikus dapat dihambat dengan pemberian ekstrak daun binahong, peningkattannya tidak seperti pada kelompok tikus yang tidak diberi perlakuan daun binahong, dan secara statistik menunjukkan adanya perbedaan yang bermakna antara kelompok B, C, D dan E.

\section{Simpulan}

Dari pembahasan tersebut dapat disimpulkan bahwa peningkatan Aktivitas kadar AST dan ALT serum darah hewan 
coba yang diinduksi paracetamol dapat dihambat oleh ekstrak daun binahong, karena daun binahong mempunyai kemampuan untuk melindungi kerusakan hepar hewan coba tikus putih, kerusakan hepar secara akut dapat terlihat dari adanya peningkatan kadar ALT lebih tinggi daripada kadar AST, sedangkan pada kerusakan hepar yang bersifat kronis kadar AST lebih tinggi dari ALT. Saran perlu dilakukan penelitian lebih lanjut dengan dosis ekstrak yang optimum dan jangka waktu penelitian lebih lama, selain itu perlu dilakukan penelitian secara histopatologis pada organ tubuh yang ingin dilihat.

\section{Daftar Pustaka}

1. Pelczar, M.J., dan Chan, E.C.S..1986. Dasar -Dasar Mikrobiologi. Jakarta : Universitas Indonesia.

2. Manoi, F. 2009. Binahong (Anredera cordifolia (Ten) Steenis) Sebagai Obat.Jurnal Warta Penelitian Dan Pengembangan Tanaman Industri. Jurnal Artikel Penelitian, (Online). Volume 15Nomor 1:3. diakses 25 Mei 2013.

3. Wijayakusuma, H., S. Dalimartha, dan A.S. Wirian. 1996. Tanaman Berkhasiat Obat di Indonesia. Jilid 4. Pustaka Kartini, Jakarta.

4. Heyne. K. (1987). Tumbuhan Berguna Indonesia. Jilid III. Badan Litbang Kehutanan, Jakarta.
5. Anonimus. 2000. Acuan Sediaan Herbal. Ditjen POM. Departemen Kesehatan RI, Jakarta

6. Setiaji, A. 2009. Uji Aktivitas Antibakteri Ekstrak Petroleum Eter, Etil Asetat Dan Etanol 70\% Rhizoma Binahong (Anredera Cordifolia (Tenore) Steen) Terhadap Staphylococcus aureus Atcc 25923 Dan Escherichia coli Atcc 11229 Serta Skrining Fitokimianya. Terdapat pada http://etd.eprints. ums.ac.id/5253/1/K100050288.pdf.di akses 25 April 2013.

7. Alan, L. dan N. D. Miller. 1996. Antioxidant flavonoids: Structure, function and clinical usage. Alt. Med. Rev. 1(2):103-111.

8. Harborne JB 1973. Phytochemical Method London, Chapman and Hall, Ltd, pp 49-188 